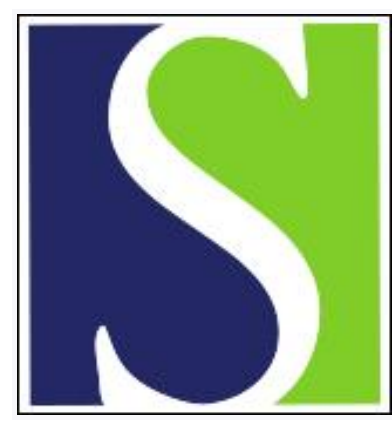

Scand J Work Environ Health 1980;6(4):299-301

https://doi.org/10.5271/sjweh.2605

Issue date: Dec 1980

Increased sister chromatid exchange frequencies in lymphocytes of nurses handling cytostatic drugs.

by Norppa H, Sorsa M, Vainio H, Gröhn P, Heinonen E, Holsti L, Nordman E

Key terms: carcinogen; chemotherapeutic drug; chromosome damage; cytostatic drug; lymphocyte; mutagen; nurse; occupational exposure; sister chromatid exchange frequency

This article in PubMed: www.ncbi.nlm.nih.gov/pubmed/7233118

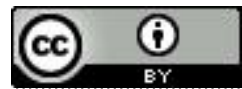




\title{
Increased sister chromatid exchange frequencies in lymphocytes of nurses handling cytostatic drugs
}

\author{
by Hannu Norppa, LSc, ${ }^{1}$ Marja Sorsa, PhD, ${ }^{1}$ Harri Vainio, MD, ${ }^{1}$ Pentti Gröhn, MD, ${ }^{2}$ \\ Erkki Heinonen, MD, ${ }^{2}$ Lars Holsti, MD, ${ }^{2}$ Eeva Nordman, MD ${ }^{3}$
}

\begin{abstract}
NORPPA H, SORSA M, VAINIO H, GRÖHN P, HEINONEN E, HOLSTI LR, NORDMAN E. Increased sister chromatid exchange frequencies in lymphocytes of nurses handling cytostatic drugs. Scand $j$ work environ health 6 (1980) 299-301. In oncology units, personnel handling chemotherapeutic drugs may occasionally be exposed to small. amounts of genotoxic agents. This exposure was obviously the cause of the increased frequencies of sister chromatid exchange (SCE) observed in nurses in daily contact with cytostatics ( $\mathrm{N}=20$, mean SCEs/cell $\pm \mathrm{SE} 9.4 \pm 0.3$ ) as compared to a group of office workers $(\mathbb{N}=10$, mean SCEs/cell $8.1 \pm 0.3)$. The oncology nurses also had a higher SCE frequency than other hospital nurses $(N=10$, mean SCEs/cell $8.7 \pm 0.2)$, but this difference was not statistically significant. The SCEs of patients under chemotherapy were about five times higher (mean SCEs/cell $36.8 \pm 10.6$ ) than those of healthy subjects.
\end{abstract}

Key terms: carcinogens, chemotherapeutic drugs, chromosome damage, mutagens, occupational exposure.

Nurses working with cytostatic drugs in an oncology unit have increased mutagenicity in their urine, as detected by a sensitive bacterial fluctuation test (2). Since this mutagenicity is obviously due to the uptake of very small amounts of cancer chemotherapeutic drugs, it was necessary to study whether such a low exposure would cause any biological response in the nurses. The analysis of sister chromatid exchanges (SCEs) in cultured blood lymphocytes of groups of people exposed in vivo to suspected genotoxic chemicals in the environment has recently offered a

1 Department of Industrial Hygiene and Toxicology, Institute of Occupational Health, Helsinki, Finland.

2 Department of Radiotherapy and Oncology, University Central Hospital, Helsinki, Finland.

3 Department of Radiotherapy and Oncology, University Central Hospital, Turku, Finland.

Reprint requests to: Dr Harri Vainio, Institute of Occupational Health, Haartmaninkatu 1 , SF-00290 Helsinki 29, Finland. promising tool for the biological monitoring of specific occupational exposures (5). A specific case of such exposure is the handling of cytostatic drugs, many of which are known mutagens, carcinogens, and inducers of SCE $(1,6,7,8,10,11,12$, 13).

\section{Subjects and methods}

The exposed subjects of the study comprised 20 nurses working in three oncology units with daily or almost daily contact with cytostatic drugs (preparation of solutions and syringes for infusion), the five most frequently used drugs being cyclophosphamide, 5-fluorouracil and analogs, methotrexate, adriamycin and cisplatinum. The following reference groups were used: ten hospital nurses working in different bedside units of the same hospital and ten persons working in various offices with no known chemical exposure. In addition five patients under therapy (cyclophosphamide as the main drug) were used 
Table 1. Sister chromatid exchange frequencies in lymphocyies of patients, hospital nurses and office personnel.

\begin{tabular}{lcccc}
\hline Group of subjects & $\begin{array}{c}\text { Number of } \\
\text { subjects }\end{array}$ & $\begin{array}{c}\text { Number of } \\
\text { cells analyzed }\end{array}$ & $\begin{array}{c}\text { SCEs/cell } \\
\text { (group mean } \pm \text { SE) }\end{array}$ & $\begin{array}{c}\text { Statistical } \\
\text { significance } \\
\text { (t-test) }\end{array}$ \\
\hline A. Patienis & 4 & 120 & $36.8 \pm 0.6$ & $\begin{array}{c}<0.001 \\
\text { (A to all groups) } \\
<0.1\end{array}$ \\
B. Oncology nurses & 20 & 600 & $9.4 \pm 0.3$ & $\begin{array}{l}\text { (B to C) } \\
\text { (B to D, B to E) }\end{array}$ \\
C. Other nurses & 10 & 300 & $8.7 \pm 0.2$ & $<0.1$ \\
D. Office personnel & 10 & 300 & $8.1 \pm 0.3$ & - \\
E. All referents (C + D) & 20 & 600 & $8.4 \pm 0.2$ & - \\
\hline
\end{tabular}

as positive controls. All the subjects were nonsmokers, except one person in the office group and one of the oncology personnel, who smoked about 10 cigarettes daily. According to blood counts and a personal interview, all the referents were healthy and had not been exposed previously to known SCE-inducing agents.

The whole-blood microculture method was used as described earlier $(4,9)$, bromodeoxyuridine (Calbiochem) being added in a concentration of $5.0 \mathrm{\mu g} / \mathrm{ml}$ for the whole culture time of $68 \mathrm{~h}$. The samples were cultured in two groups and analyzed

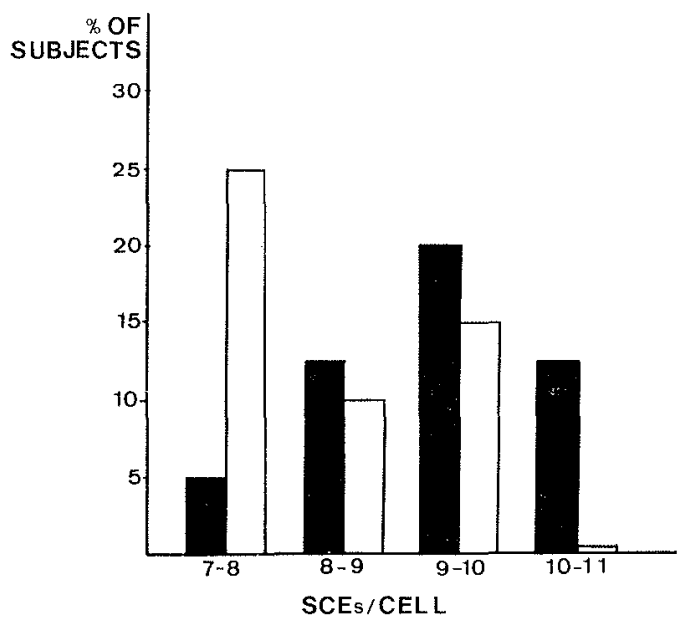

Fig 1. Distribution of individual sister chromatid exchange (SCE) frequencies for 20 oncology nurses (filled columns) and 20 referents, 10 nurses and 10 office workers (unfilled columns). by one person on coded slides, 30 harlequin-stained metaphases from each subject.

\section{Results}

The SCE frequencies of the four groups. of subjects are given in table 1. The SCEs of the patients under therapy were five to six times higher than those of the other subjects (no result could be obtained from one patient). Also the oncology nurses. generally had higher SCE frequencies than the office personnel, their group mean of $\mathrm{SCE} /$ cell deviating significantly $(\mathrm{p}<0.01$, one-tailed Student's t-test) from that of the office workers but not significantly ( $p<0.1$ ) from that of the other hospital nurses. Also the distribution of individual mean SCE frequencies/cell (fig 1) clearly revealed a tendency towards higher individual SCE rates among the nurses handling cytostatics as compared with the two groups of referents.

\section{Discussion}

The previous findings of increased mutagenicity in the urine of nurses (2) suggested that some exposure to anticancer drugs may occur. Many of the chemotherapeutics used, eg, adriamycin $(10,11)$, 1-[2-chloroethyl-3-(4-methyl-cyclohexy1)]1-nitrosourea (CCNU) (7, 8), cyclophosphamide $(10,12)$, and cis-platinum (13) have been shown to be potent inducers of 
SCE in patients or in experimental systems, and thus the increased SCE frequencies among nurses handling cytostatic drugs can be attributed to this occupational exposure. In the present study the increased frequency of SCEs in the blood lymphocytes of nurses handling cytostatics was of the same order of magnitude as that found earlier for smoking subjects (4). Another recent study (14) revealed an increase not only in SCEs, but also in chromosome aberration frequencies among nurses handling cytostatic drugs.

Hospital work as such may involve some exposure to mutagenic chemicals (eg, drugs, sterilizing agents, solvents). Personnel in hormone and research laboratories have been reported to have increased SCE frequencies in comparison to referents (3). In the present material, the SCE frequency of the oncology nurses and the nurses from other hospital departments did not differ statistically significantly, neither did the hospital referents show a statistically higher SCE frequency than the office personnel.

The biological response in the SCEs of oncology nurses points to a possible genotoxic hazard and to the need for careful hygienic measures during the handling of cytostatic drugs.

\section{References}

1. Banerjee A, Benedict WF. Production of sister chromatid exchanges by various chemotherapeutic agents. Cancer res 39 (1979) 797-799.

2. Falck K, Gröhn P, Sorsa M, Vainio H, Heinonen E, Holsti LR. Mutagenicity in urine of nurses handling cytostatic drugs. Lancet 1 (1979) 1250-1251.

3. Funes-Cravioto F, Zapata-Gayon C, Kolmodin-Hedman B, Lamber B, Lindsten J, Nordberg E, Nordensljöld $M$, Olin R, Swensson $\AA$. Chromosome aberrations and sister chromatid exchange in workers of chemical laboratories and a rotoprinting factory and in children of women laboratory workers. Lancet 1 (1977) 322-325.
4. Husgafvel-Pursiainen $K$, Mäki-Paakkanen J, Norppa H, Sorsa M. Smoking and sister chromatid exchange. Hereditas 92 (1980) $247-250$.

5. Lambert B, Lindblad A, Holmberg $\mathrm{K}$, Francesconi D. Use of sister chromatid exchange to monitor human populations for exposure to toxicologically harmful agents. In: Wolff S, ed. Sister chromatid exchange. John Wiley \& Sons, New York, NY (in press).

6. Lambert B, Ringborg $\mathrm{V}$, Harper $\mathrm{E}$, Lindblad A. Sister chromatid exchanges in lymphocyte cultures of patients receiving chemotherapy for malignant disorders. Cancer treat rep 62 (1978) $1413-1419$.

7. Lambert B, Ringborg U, Lindblad A. Prolonged increase of sister chromatid exchanges in lymphocytes of melanoma patients after CCNU treatment. Nutat res 59 (1979) 295-300.

8. Lambert $B$, Ringborg $U$, Lindblad A, Sten M. The effects of DTIC, melphalan, actinomycin $D$ and CCNU on the frequency of sister chromatid exchanges in peripheral blood of melanoma patients. In: Jones SE, Salmon WE, ed. Adjuvant therapy of cancer II. Grune \& Stratton, New York, NY 1979, pp 55-61.

9. Mäki-Paakkanen $J$, Husgafvel-Pursiainen $K$, Kalliomäki P-L, Tuominen J, Sorsa M. Toluene-exposed workers and chromosome aberrations. J toxicol environ health 6 (1980) $775-781$.

10. Musilova J, Michalová K, Urban J. Sisterchromatid exchanges and chromosomal breakage in patients treated with cytostatics. Mutat res 67 (1979) 289-294.

11. Nevstad NP. Sister chromatid exchanges and chromosomal aberrations induced in human lymphocytes by the cytostatic drug adriamycin in vivo and in vitro. Mutat res 57 (1978) 253-258.

12. Raposa T. Sister chromatid exchange studies for monitoring DNA damage and repair capacity after cytostatics in vitro and in lymphocytes of leukaemic patients under cytostatic therapy. Mutat res 57 (1978) $241-251$.

13. Turnbull D, Popescu NC, DiPaolo JA, Myhr BC. cis-Platinum(II)diamine dichloride causes mutation, transformation, and sister-chromatid exchanges in cultured mammalian cells. Mutat res 66 (1979) $267-275$.

14. Waksvik H, Brøgger A, Klepp O. Chromosome analyses of nurses handling cytostatic drugs. Cancer treat rep (in press).

Received for publication: 10 October 1980 